\title{
Low Dose Carbon Black Nanoparticle Exposure Does Not Aggravate Allergic Airway Inflammation in Mice Irrespective of the Presence of Surface Polycyclic Aromatic Hydrocarbons
}

\author{
Karina Lindner ${ }^{1,+}$, Sina Webering ${ }^{2,+}$, Michael Stroebele $^{3}$, Henning Bockhorn ${ }^{3}$, Tanja Hansen ${ }^{4}$, \\ Peter König ${ }^{1,+}$ and Heinz Fehrenbach ${ }^{2, *}+$ \\ 1 Institut für Anatomie, Zentrum für medizinische Struktur- und Zellbiologie, Universität zu Lübeck (UzL), \\ Airway Research Center North (ARCN), Member of the German Center for Lung Research (DZL), \\ 23562 Lübeck, Germany; lindner@anat.uni-luebeck.de (K.L.); koenig@anat.uni-luebeck.de (P.K.) \\ 2 Forschungszentrum Borstel, Leibniz Lungen-Zentrum, Experimentelle Pneumologie, Airway Research \\ Center North (ARCN), Member of the German Center for Lung Research (DZL), 23845 Borstel, Germany; \\ swebering@fz-borstel.de \\ 3 Karlsruher Institut für Technologie, Engler-Bunte-Institut, Bereich Verbrennungstechnik, 76313 Karlsruhe, \\ Germany; michael.stroebele@kit.edu (M.S.); henning.bockhorn@kit.edu (H.B.) \\ 4 Fraunhofer Institut für Toxikologie und Experimentelle Medizin ITEM, Hannover, Biomedical Research in \\ Endstage and Obstructive Lung Disease Hannover (BREATH), Member of the German Center for Lung \\ Research (DZL), 30625 Hannover, Germany; tanja.hansen@item.fraunhofer.de \\ * Correspondence: hfehrenbach@fz-borstel.de; Tel.: +49-(0)4537-188-7290, Fax: +49-(0)4537-188-4906 \\ + These authors contributed equally to the work described herein.
}

Received: 18 February 2018; Accepted: 29 March 2018; Published: 31 March 2018

\begin{abstract}
Exposure to exogenous noxae, such as particulate matter, can trigger acute aggravations of allergic asthma-a chronic inflammatory airway disease. We tested whether Carbon Black nanoparticles (CBNP) with or without surface polycyclic aromatic hydrocarbons (PAH) aggravate an established allergic airway inflammation in mice. In an ovalbumin mouse model, Printe ${ }^{\circledR} 90$ (P90), P90 coated with benzo[a]pyrene (P90-BaP) or 9-nitroanthracene (P90-9NA), or acetylene soot exhibiting a mixture of surface PAH (AS-PAH) was administered twice $(70 \mu \mathrm{L}, 100 \mu \mathrm{g} / \mathrm{mL})$ during an established allergic airway inflammation. We analyzed the immune cell numbers and chemokine/cytokine profiles in bronchoalveolar lavages, the mRNA expressions of markers for PAH metabolism (Cyp1a1, 1b1), oxidative stress (HO-1, Gr, Gpx-3), inflammation (KC, Mcp-1, IL-6, IL-13, IL-17a), mucin synthesis (Muc5ac, Muc5b), the histology of mucus-producing goblet cells, ciliary beat frequency (CBF), and the particle transport speed. CBNP had a comparable primary particle size, hydrodynamic diameter, and $\zeta$-potential, but differed in the specific surface area $(\mathrm{P} 90>\mathrm{P} 90-\mathrm{BaP}=$ P90-9NA = AS-PAH) and surface chemistry. None of the CBNP tested increased any parameter related to inflammation. The unmodified P90, however, decreased the tracheal CBF, decreased the Muc5b in intrapulmonary airways, but increased the tracheal Muc5ac. Our results demonstrated that irrespective of the surface PAH, a low dose of CBNP does not acutely aggravate an established allergic airway inflammation in mice.
\end{abstract}

Keywords: asthma; allergic airway inflammation; mucociliary clearance; carbon black nanoparticles; polycyclic aromatic hydrocarbons; exacerbation 


\section{Introduction}

Asthma is a common airway disease with more than 241 million prevalent cases worldwide in 2013 [1]. During an acute asthmatic response, the sufferer's breathing is limited by an obstruction of the airway induced by smooth muscle constriction and mucus plugs in the airway lumen [2-4]. Moreover, asthmatic responses are associated with increased mucus secretion from goblet cells, epithelial injury, cellular infiltrations of immune cells, hyperplasia of smooth muscles, and deposition of excess collagen [2,5-8]. Asthma patients experience 0.3-3 acute aggravations of their symptoms per year-called asthma exacerbations-requiring an increase in their medication [9]. Because an exacerbation may require an emergency department visit or the hospitalization of the patient, asthma exacerbations are the main cost drivers of this chronic airway disease. Asthma exacerbations can be triggered by a variety of factors including air pollution [10].

Clinical and epidemiologic studies indicated that fine particles $(<2.5 \mu \mathrm{m})$ and nanoparticles $(<100 \mathrm{~nm})$ from urban airborne particulate matter (PM) contributed to asthma exacerbation [11-13], showing an increased use of asthma medication [14], the reduction of lung function, and the increase of bronchial hyper-reactivity, as well as sputum IL-6 levels in subjects with asthma [13,15], after exposure to traffic-related air pollution.

The main sources of urban pollution are exhaust particles that contain carbonaceous particles with surface-bound substances such as polycyclic aromatic hydrocarbons (PAH) [16,17]. PAH are typically detected as complex mixtures containing low and high molecular weight PAH $[18,19]$. Low molecular weight PAH which have a 2- to 4-ring system—such as anthracene-are considered to be low-carcinogenic, whereas high molecular weight $\mathrm{PAH} —$ such as benzo[a]pyrene (BaP)—consist of more than 4 rings and are classified as high-carcinogenic [20]. The acute effects of PAH alone or when PAH are bound to Carbon Black nanoparticles (CBNP) comprise the induction of oxidative stress, cell death, and inflammation [21-23], indicating a possible contribution to asthmatic exacerbation [24].

Previous studies in animals, in which model allergens such as ovalbumin (OVA) were used to induce an allergic airway inflammation, showed that defined CBNP-such as Printex ${ }^{\circledR} 90$ (P90)-can aggravate the allergic airway inflammation [25-27] and hyperresponsiveness [28], and can increase the number of goblet cells in the intrapulmonary airways $[25,26,28]$. The CBNP used represent the carbonaceous core of exhaust particles [16,17] but do not reflect the physicochemical characteristics of naturally occurring particles that exhibit chemical surface modifications.

In the present study, we analyzed the acute effects of the defined CBNP to clarify whether surface-bound PAH enhance the potential of CBNP to trigger the aggravation of an established allergic airway inflammation and/or whether it may affect the mucociliary clearance. We used P90 as reference particles and coated them with PAH, either BaP or 9-nitroanthracene (9NA). Additionally, we tested soot that contained a mixture of surface-bound PAH generated from acetylene by flame synthesis [21].

Based on current reports that analyzed the content of fine and ultrafine particles in the air of European and Asian cities [29-31], and an experimental study that tested a low dose of P90 in a mouse model [32], we calculated a low dose exposure regimen for our experimental setting in order to avoid particle overload, which might overlap with any surface-specific particle effects. The CBNP were administered to OVA-sensitized animals during an acute asthmatic response induced by pulmonary OVA challenges. In contrast to previous studies [25,27], the asthma model used in our experiments reflects the three main features of asthma: airway hyperresponsiveness to methacholine, eosinophilic airway inflammation, and goblet cell metaplasia, which are aggravated by an additional trigger such as poly(I:C) [33]. Therefore, our experimental model might be superior for the assessment of the effects of CBNP in an asthmatic lung. Since airway remodeling associated with asthma differs in the proximal and distal airways, we not only analyze whether the CBNP aggravate the allergic airway inflammation due to their specific surface characteristics but also whether the reaction to the CBNP is different in the intrapulmonary and proximal airways. 


\section{Results}

\subsection{Characterization of CBNP and Their Suspensions}

The CBNP were characterized with regards to the primary particle size, the specific surface area, the mass loss during heating up to $1000{ }^{\circ} \mathrm{C}$, and their characteristics in aqueous suspension such as their hydrodynamic diameter and zeta (乙)-potential. The data are presented in Table 1. The P90 nanoparticles and P90-9NA were already used in a previous study showing the transmission and scanning electron microscopic images and the particle size distribution of P90 particles, and the mass loss of P90-9NA as a function of the increased temperature [21]. In the present study, a new batch of P90-BaP and AS-PAH was used. Electron microscopic images and the size distribution of AS-PAH without the PAH, the mass loss up to $700{ }^{\circ} \mathrm{C}$ of P90-BaP and AS-PAH, and the PAH species identified on the surface of AS-PAH are shown in Figure S1 and Table S1.

Table 1. Particle characteristics.

\begin{tabular}{|c|c|c|c|c|}
\hline Particle Characteristics & Printex ${ }^{\circledR} 90$ (P90) & $\begin{array}{l}\text { P90 Coated with } \\
\text { benzo[a]pyrene } \\
\text { (P90-BaP) }\end{array}$ & $\begin{array}{l}\text { P90 Coated with } \\
\text { 9-Nitroanthracene } \\
\text { (P90-9NA) }\end{array}$ & $\begin{array}{c}\text { Acetylene Soot } \\
\text { with PAH-Mixture } \\
\text { (AS-PAH) }\end{array}$ \\
\hline Mean primary particle size $(\mathrm{nm})$ & $16.5 \pm 0.4$ & $16.5 \pm 0.4^{*}$ & $16.5 \pm 0.4^{*}$ & $14.4 \pm 0.3^{*}$ \\
\hline Specific surface area $\left(\mathrm{m}^{2} / \mathrm{g}\right)$ & $302 \pm 16$ & $120 \pm 2$ & $91^{\#}$ & $124 \pm 2$ \\
\hline Mass loss up to $1000^{\circ} \mathrm{C}(\%)$ & $0.5 \pm 0.4$ & $10.0 \pm 0.2$ & $14.6 \pm 0.1$ & $15.3 \pm 0.2$ \\
\hline $\begin{array}{c}\text { Hydrodynamic diameter in } \\
\text { water/BSA }(\mathrm{nm})\end{array}$ & $166 \pm 9$ & $163 \pm 6$ & $161 \pm 3$ & $163 \pm 6$ \\
\hline$\zeta$-potential in water/BSA $(\mathrm{mV})$ & $-33 \pm 1$ & $-32 \pm 1$ & $-33 \pm 1$ & $-32 \pm 1$ \\
\hline
\end{tabular}

Data are mean \pm SEM. $n=3-6$, except ${ }^{\#} n=1,{ }^{*}$ measurement without surface modifications.

All particles have a similar mean primary particle size, hydrodynamic diameter, and $\zeta$-potential in water with $0.5 \%$ BSA. P90 exhibits a larger surface area and a smaller mass loss compared to the BaPand 9NA-coated P90 particles and AS-PAH. The mass loss of P90-BaP and P90-9NA correlates with the content of BaP and 9NA adsorbed on the P90 surface. The identified PAH species that cover the surface of AS-PAH are shown in Table S1. We detected a mixture of at least 12 different PAH species with 2 to 5 aromatic rings. In the CBNP suspensions that were used, no endotoxins were measurable.

\subsection{CBNP Did Not Increase Inflammatory Parameters in the Lungs of OVA-Treated Mice}

The allergic airway inflammation is associated with several changes in the lungs of animals of the OVA control group. Compared to the PBS control group, the relative lung weight (Figure 1a and Figure S2) and the parameters analyzed in the fluid from bronchoalveolar lavages (BALs) — the cell numbers of macrophages, lymphocytes, and granulocytes (Figure 1b), as well as the inflammation-related cytokines such as IL-5, IL-13, IL-6, IL-1 3, KC, and Mcp-1 (Table 2)-were increased in the OVA control group. In addition, the airway hyperresponsiveness to methacholine was increased in the OVA control group compared to the PBS control group (Figure 1c).

The exposure to CBNP did not increase the relative lung wet weight (Figure 1a) nor the number of immune cells (Figure 1b) or inflammatory cytokines (Table 2) in the BAL fluid, and the airway hyperresponsiveness to methacholine was not different from OVA $/ \mathrm{H}_{2} \mathrm{O}$ treated mice (Figure 1c).

However, we observed some significant decreases after CBNP-exposure compared to the OVA/ $\mathrm{H}_{2} \mathrm{O}$ group: (i) P90 reduced IL-13 (Table 2); (ii) P90-BaP and P90-9NA decreased the number of eosinophils (Figure 1b), and reduced IL-4 (P90-BaP) or IL-1 $\beta$ and IL-13 (P90-9NA) (Table 2); (iii) AS-PAH reduced IL-4 and IL-1 $\beta$ (Table 2) in the BAL fluid. The reduction of Mcp-1 protein level in the BAL fluid was observed after exposure to all CBNP tested (Table 2). 
(a)

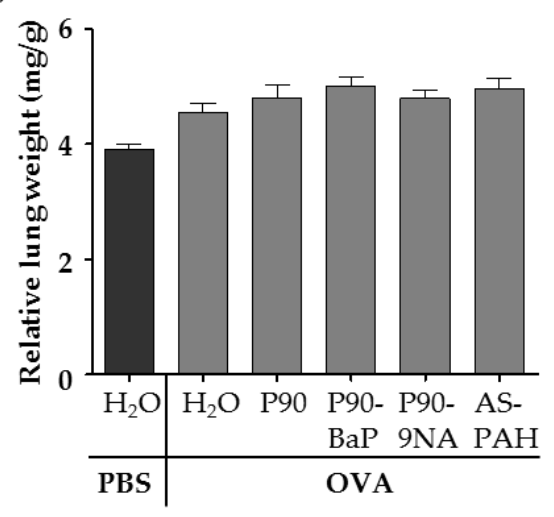

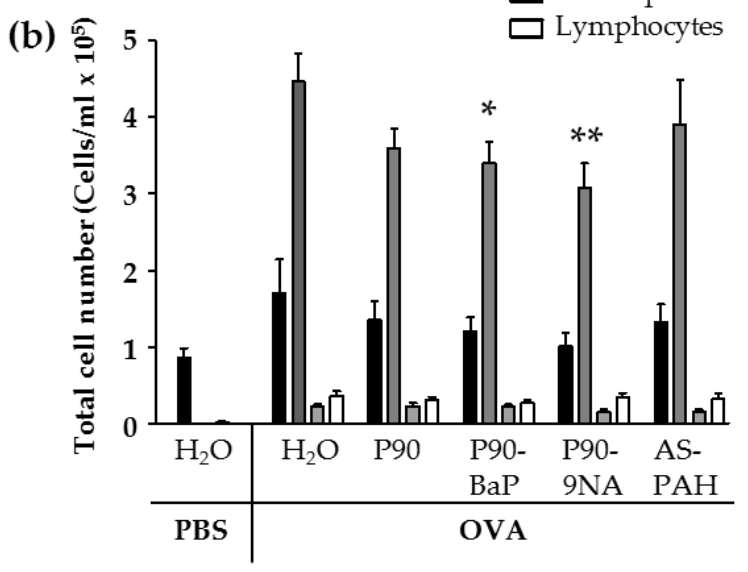

(c)

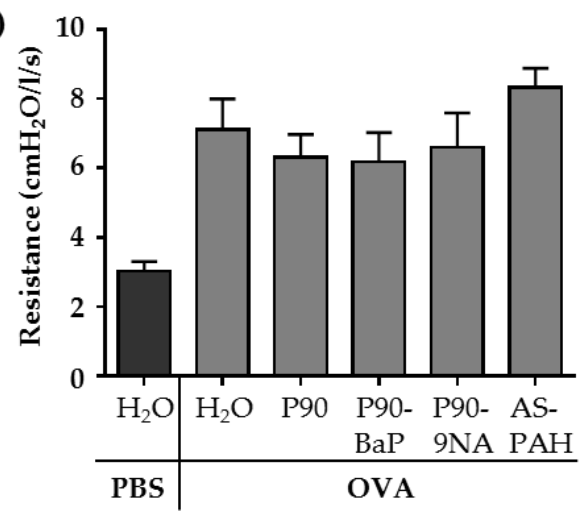

Figure 1. CBNP did not aggravate the inflammation in the lungs. The diagram in (a) shows the relative lung weight calculated from the quotient of the absolute wet weight of the left lung and the body weight of mouse $(n=13-18)$. The diagram in (b) shows the results of the differential cell count of immune cells detected in the brochoalveolar lavage (BAL) fluid $(n=18-25)$. The diagram in (c) shows the results of the airway resistance in response to $100 \mathrm{mg} / \mathrm{mL}$ methacholine $(n=7-8)$. All data are presented as mean $\pm \mathrm{SEM}$. The OVA/CBNP groups were compared to the $\mathrm{OVA} / \mathrm{H}_{2} \mathrm{O}$ group and analyzed by the Mann Whitney U test. Significant changes were marked with ${ }^{*}$ for $p<0.05$ and ${ }^{* *}$ for $p<0.01$.

Table 2. Cytokine and chemokine levels in the bronchoalveolar lavage (BAL) fluid.

\begin{tabular}{ccccccc}
\hline Protein & $\mathbf{P B S} / \mathbf{H}_{\mathbf{2}} \mathbf{O}$ & $\mathbf{O V} / \mathbf{H}_{\mathbf{2}} \mathbf{O}$ & OVA/P90 & OVA/P90-BaP & OVA/P90-9NA & OVA/AS-PAH \\
\hline Mcp-1 & $0.01 \pm 0.01$ & $27.0 \pm 5.7$ & $\mathbf{1 2 . 7} \pm \mathbf{3 . 9} *$ & $\mathbf{7 . 4} \pm \mathbf{5 . 5}$ & $\mathbf{1 1 . 7} \pm \mathbf{5 . 7}$ & $\mathbf{0 . 6} \pm \mathbf{0 . 3}^{*}$ \\
KC & $9.5 \pm 2.3$ & $21.6 \pm 5.7$ & $16.7 \pm 4.3$ & $17.7 \pm 4.2$ & $21.3 \pm 7.9$ & $9.9 \pm 2.5$ \\
IL-1 $\beta$ & $0.06 \pm 0.02$ & $1.3 \pm 0.2$ & $0.8 \pm 0.2$ & $0.8 \pm 0.2$ & $\mathbf{0 . 7} \pm \mathbf{0 . 2} *$ & $\mathbf{0 . 5} \pm \mathbf{0 . 1}^{*}$ \\
IL-6 & $0.4 \pm 0.1$ & $1.1 \pm 0.3$ & $0.8 \pm 0.2$ & $0.7 \pm 0.1$ & $0.7 \pm 0.2$ & $0.7 \pm 0.2$ \\
IL-4 & $0.8 \pm 0.6$ & $1.2 \pm 0.2$ & $0.7 \pm 0.1$ & $\mathbf{0 . 7} \pm \mathbf{0 . 1}$ & $0.9 \pm 0.2$ & $\mathbf{0 . 6} \pm \mathbf{0 . 2}$ \\
IL-5 & $0.8 \pm 0.3$ & $12.7 \pm 2.1$ & $10.4 \pm 1.8$ & $13.4 \pm 1.8$ & $11.1 \pm 1.8$ & $11.7 \pm 2.2^{*}$ \\
IL-13 & $0.03 \pm 0.01$ & $7.3 \pm 1.1$ & $\mathbf{4 . 4} \pm \mathbf{0 . 9} *$ & $5.7 \pm 1.1$ & $\mathbf{4 . 4} \pm \mathbf{0 . 6} *$ & $5.4 \pm 1.2$ \\
IL-17A & $0.2 \pm 0.1$ & $0.4 \pm 0.1$ & $0.3 \pm 0.1$ & $0.3 \pm 0.1$ & $0.4 \pm 0.1$ & $0.3 \pm 0.1$ \\
\hline
\end{tabular}

The concentration unit is $\mathrm{pg} / \mathrm{mL}$. Data are presented as mean \pm SEM $(n=11-16)$. The OVA/CBNP groups were compared to the OVA $/ \mathrm{H}_{2} \mathrm{O}$ group and analyzed with the Mann Whitney U test. Significant changes were marked with * for $p<0.05$. 
2.3. CBNP Did Not Increase the mRNA Expression of Inflammatory-Relevant Markers in the Tracheal Epithelial Cells and Intrapulmonary Airways of OVA-Treated Mice

Since the airways and airway epithelial cells play a pivotal role in the modulation of the inflammatory response-for example, as a site of host defense and cytokine production-we analyzed the mRNA expression of markers for PAH metabolism, oxidative stress, and inflammation in tracheal epithelial cells and intrapulmonary airways.

PAH are metabolized by cytochrome P450 enzymes Cyp1a1 and Cyp1b1, resulting in toxic modifications. Our results demonstrated that the exposure to CBNP did not increase the mRNA expression of both Cyp enzymes in tracheal epithelial and intrapulmonary airways compared to the OVA $/ \mathrm{H}_{2} \mathrm{O}$ group (Table 3).

Table 3. The mRNA expression of the relevant markers for PAH metabolism, oxidative stress, and inflammation.

\begin{tabular}{|c|c|c|c|c|c|c|c|}
\hline Gene & Airway Section & $\mathrm{PBS} / \mathrm{H}_{2} \mathrm{O}$ & $\mathrm{OVA} / \mathrm{H}_{2} \mathrm{O}$ & OVA/P90 & $\begin{array}{l}\text { OVA/P90- } \\
\text { BaP }\end{array}$ & $\begin{array}{l}\text { OVA/P90- } \\
\text { 9NA }\end{array}$ & $\begin{array}{l}\text { OVA/AS- } \\
\text { PAH }\end{array}$ \\
\hline Cyp1a1 & $\begin{array}{l}\text { intrapulmonary airways } \\
\text { tracheal epithelial cells }\end{array}$ & $\begin{array}{l}1.0 \pm 0.1 \\
\text { bld }\end{array}$ & $\begin{array}{l}1.0 \pm 0.2 \\
\text { bld }\end{array}$ & $\begin{array}{l}1.3 \pm 0.4 \\
\text { bld }\end{array}$ & $\begin{array}{l}1.3 \pm 0.2 \\
\text { bld }\end{array}$ & $\begin{array}{l}0.7 \pm 0.1 \\
\text { bld }\end{array}$ & $\begin{array}{l}1.5 \pm 0.3 \\
\text { bld }\end{array}$ \\
\hline Cyp1b1 & $\begin{array}{l}\text { intrapulmonary airways } \\
\text { tracheal epithelial cells }\end{array}$ & $\begin{array}{l}1.0 \pm 0.1 \\
1.1 \pm 0.2\end{array}$ & $\begin{array}{l}0.6 \pm 0.1 \\
1.2 \pm 0.3\end{array}$ & $\begin{array}{l}0.6 \pm 0.1 \\
1.4 \pm 0.3\end{array}$ & $\begin{array}{l}0.8 \pm 0.1 \\
1.3 \pm 0.4\end{array}$ & $\begin{array}{l}0.5 \pm 0.1 \\
1.6 \pm 0.7\end{array}$ & $\begin{array}{l}0.9 \pm 0.1 \\
2.8 \pm 0.9\end{array}$ \\
\hline Gpx3 & $\begin{array}{l}\text { intrapulmonary airways } \\
\text { tracheal epithelial cells }\end{array}$ & $\begin{array}{l}1.0 \pm 0.1 \\
1.0 \pm 0.1\end{array}$ & $\begin{array}{l}0.9 \pm 0.1 \\
0.3 \pm 0.1\end{array}$ & $\begin{array}{l}0.8 \pm 0.1 \\
0.6 \pm 0.1\end{array}$ & $\begin{array}{l}1.0 \pm 0.1 \\
0.3 \pm 0.1\end{array}$ & $\begin{array}{l}1.0 \pm 0.1 \\
0.3 \pm 0.1\end{array}$ & $\begin{array}{l}1.0 \pm 0.1 \\
0.4 \pm 0.1\end{array}$ \\
\hline$G r$ & $\begin{array}{l}\text { intrapulmonary airways } \\
\text { tracheal epithelial cells }\end{array}$ & $\begin{array}{l}1.0 \pm 0.1 \\
1.0 \pm 0.2\end{array}$ & $\begin{array}{l}1.3 \pm 0.1 \\
1.1 \pm 0.4\end{array}$ & $\begin{array}{l}1.1 \pm 0.1 \\
1.5 \pm 0.3\end{array}$ & $\begin{array}{l}1.5 \pm 0.1 \\
0.9 \pm 0.3\end{array}$ & $\begin{array}{l}1.0 \pm 0.1 \\
0.8 \pm 0.2\end{array}$ & $\begin{array}{l}1.5 \pm 0.1 \\
0.9 \pm 0.4\end{array}$ \\
\hline $\mathrm{HO}-1$ & $\begin{array}{l}\text { intrapulmonary airways } \\
\text { tracheal epithelial cells }\end{array}$ & $\begin{array}{l}1.0 \pm 0.1 \\
1.2 \pm 0.3\end{array}$ & $\begin{array}{l}1.3 \pm 0.1 \\
1.0 \pm 0.2\end{array}$ & $\begin{array}{l}1.1 \pm 0.1 \\
1.1 \pm 0.2\end{array}$ & $\begin{array}{l}1.1 \pm 0.1 \\
1.1 \pm 0.2\end{array}$ & $\begin{array}{l}1.1 \pm 0.1 \\
1.1 \pm 0.4\end{array}$ & $\begin{array}{l}1.2 \pm 0.1 \\
1.1 \pm 0.3\end{array}$ \\
\hline Mcp-1 & $\begin{array}{l}\text { intrapulmonary airways } \\
\text { tracheal epithelial cells }\end{array}$ & $\begin{array}{l}1.0 \pm 0.6 \\
1.1 \pm 0.3\end{array}$ & $\begin{array}{c}12 \pm 5 \\
1.2 \pm 0.3\end{array}$ & $\begin{array}{c}11 \pm 4 \\
1.8 \pm 0.6\end{array}$ & $\begin{array}{c}10 \pm 4 \\
0.4 \pm 0.1\end{array}$ & $\begin{aligned} 8 & \pm 3 \\
0.5 & \pm 0.2\end{aligned}$ & $\begin{array}{c}11 \pm 4 \\
1.1 \pm 0.5\end{array}$ \\
\hline$K C$ & $\begin{array}{l}\text { intrapulmonary airways } \\
\text { tracheal epithelial cells }\end{array}$ & $\begin{array}{l}1.0 \pm 0.3 \\
1.7 \pm 0.2\end{array}$ & $\begin{array}{l}2.1 \pm 0.6 \\
\text { bld }\end{array}$ & $\begin{array}{c}1.7 \pm 0.3 \\
\text { bld }\end{array}$ & $\begin{array}{l}1.9 \pm 0.3 \\
\text { bld }\end{array}$ & $\begin{array}{l}1.1 \pm 0.2 \\
\text { bld }\end{array}$ & $\begin{array}{l}1.5 \pm 0.3 \\
\text { bld }\end{array}$ \\
\hline$I L-6$ & $\begin{array}{l}\text { intrapulmonary airways } \\
\text { tracheal epithelial cells }\end{array}$ & $\begin{array}{l}1.0 \pm 1.3 \\
1.2 \pm 0.3\end{array}$ & $\begin{array}{l}7.9 \pm 1.2 \\
1.5 \pm 0.6\end{array}$ & $\begin{array}{l}6.8 \pm 1.4 \\
2.4 \pm 1.3\end{array}$ & $\begin{array}{l}8.5 \pm 1.0 \\
3.1 \pm 1.7\end{array}$ & $\begin{array}{l}4.3 \pm 0.5 * \\
0.6 \pm 0.3\end{array}$ & $\begin{array}{l}5.7 \pm 0.8 \\
3.5 \pm 1.8\end{array}$ \\
\hline$I L-13$ & $\begin{array}{l}\text { intrapulmonary airways } \\
\text { tracheal epithelial cells }\end{array}$ & $\begin{array}{l}1.0 \pm 0.4 \\
1.1 \pm 0.3\end{array}$ & $\begin{array}{c}52 \pm 8 \\
41 \pm 14\end{array}$ & $\begin{array}{l}40 \pm 7 \\
27 \pm 7\end{array}$ & $\begin{array}{l}48 \pm 7 \\
20 \pm 9\end{array}$ & $\begin{array}{l}34 \pm 4^{*} \\
26 \pm 10\end{array}$ & $\begin{array}{c}48 \pm 7 \\
31 \pm 10\end{array}$ \\
\hline$I L-17 a$ & $\begin{array}{l}\text { intrapulmonary airways } \\
\text { tracheal epithelial cells }\end{array}$ & $\begin{array}{l}1.0 \pm 2.9 \\
\text { bld }\end{array}$ & $\begin{array}{l}13 \pm 3 \\
\text { bld }\end{array}$ & $\begin{array}{l}13 \pm 3 \\
\text { bld }\end{array}$ & $\begin{array}{l}11 \pm 1 \\
\text { bld }\end{array}$ & $\begin{array}{c}8 \pm 2 \\
\text { bld }\end{array}$ & $\begin{array}{l}19 \pm 4 \\
\text { bld }\end{array}$ \\
\hline Muc5ac & $\begin{array}{l}\text { intrapulmonary airways } \\
\text { tracheal epithelial cells }\end{array}$ & $\begin{array}{l}1.0 \pm 0.3 \\
1.1 \pm 0.3\end{array}$ & $\begin{array}{l}44 \pm 11 \\
35 \pm 10\end{array}$ & $\begin{array}{c}29 \pm 4 \\
101 \pm 15^{* *}\end{array}$ & $\begin{array}{c}52 \pm 9 \\
38 \pm 11\end{array}$ & $\begin{array}{c}26 \pm 5 \\
39 \pm 23\end{array}$ & $\begin{array}{l}82 \pm 25 \\
39 \pm 20\end{array}$ \\
\hline$M u c 5 b$ & $\begin{array}{l}\text { intrapulmonary airways } \\
\text { tracheal epithelial cells }\end{array}$ & $\begin{array}{l}1.0 \pm 0.2 \\
1.1 \pm 0.2\end{array}$ & $\begin{array}{c}31 \pm 5 \\
2.2 \pm 0.6\end{array}$ & $\begin{array}{l}18 \pm 3^{*} \\
2.2 \pm 0.2\end{array}$ & $\begin{array}{c}32 \pm 4 \\
2.1 \pm 0.2\end{array}$ & $\begin{array}{c}20 \pm 2 \\
2.2 \pm 0.4\end{array}$ & $\begin{aligned} 39 & \pm 11 \\
2.4 & \pm 0.4\end{aligned}$ \\
\hline
\end{tabular}

Data are presented as mean \pm SEM $(n=4-8)$. The OVA/CBNP groups were compared to the OVA $/ \mathrm{H}_{2} \mathrm{O}$ group and analyzed with the Mann Whitney U test. Significant changes were marked with ${ }^{*}$ for $p<0.05$ and ${ }^{* *}$ for $p<0.01$. bld = below limit of detection

A main effect of the nanoparticles is the induction of oxidative stress. Therefore, we analyzed the mRNA expression of oxidative stress markers glutathione peroxidase 3 (Gpx3), glutathione reductase (Gr), and heme oxygenase (HO-1).

After CBNP-exposure, the mRNA expression of the three oxidative stress markers did not increase, compared to the OVA controls, neither in tracheal epithelial cells nor in intrapulmonary airways (Table 3).

The cells in the airways also contributed to the recruitment of immune cells into the lung by the release of inflammatory cytokines and chemokines. For this reason, we analyzed the mRNA expression of monocyte chemoattractant protein-1 (Mcp-1), an murine homolog of human IL-8 (KC), and the interleukins IL-6, IL-13, and IL-17a.

Our results showed that no CBNP increased the mRNA expression of the analyzed inflammatory markers (Table 3). Indeed, P90-9NA significantly decreased the mRNA expression of IL-6 and IL-13 in intrapulmonary airways compared to the OVA $/ \mathrm{H}_{2} \mathrm{O}$ group (Table 3). 


\subsection{CBNP Did Not Increase the Number of Airway Epithelial Goblet Cells in OVA-Treated Mice}

In asthma, the composition of the airway epithelium differs from healthy individuals showing, for example, an increased number of goblet cells filled with mucus. To determine the contribution of CBNP to mucus production, we analyzed the mRNA expression of the mucins Muc5b and Muc5ac, and the surface area covered by goblet cells and the volume of stored mucus in the intrapulmonary airways as well as the number of goblet cells in the tracheal epithelium using staining with periodic acid-Schiff (PAS) reagent.

Our results showed that the exposure to the PAH-containing CBNP, P90-BaP, P90-9NA, and AS-PAH, did not change the mRNA expression of the mucins compared to the $\mathrm{OVA} / \mathrm{H}_{2} \mathrm{O}$ group (Table 3). However, P90 had different effects in the tracheal and intrapulmonary epithelial cells. P90 increased the mRNA expression of Muc5ac in the tracheal epithelial cells and decreased the mRNA expression of Muc5b in the intrapulmonary airways (Table 3).

The PAS staining of the lung slices showed that the exposure to CBNP did not increase the surface covered by goblet cells nor the stored mucus volume in intrapulmonary airways compared to the OVA $/ \mathrm{H}_{2} \mathrm{O}$ group (Figure 2a-c). Since P90 increased the Muc5ac mRNA expression in the tracheal epithelial cells, we additionally stained the tracheal epithelium after exposure to P90 with PAS. The results showed that the number of PAS-positive cells was not increased after P90-exposure compared to the OVA/ $\mathrm{H}_{2} \mathrm{O}$ group (Figure $2 \mathrm{~d}, \mathrm{e}$ ).

(a)

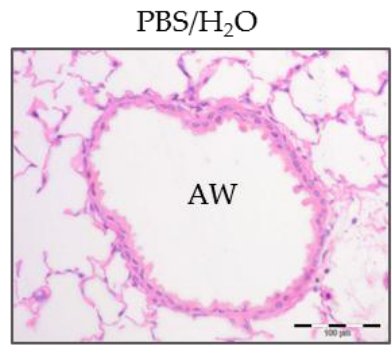

OVA/P90-BaP

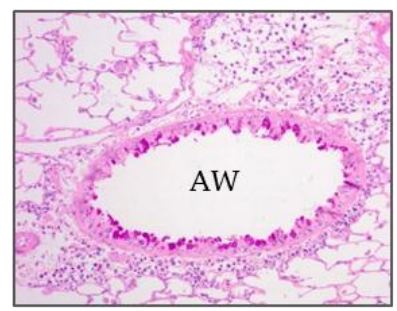

(b)

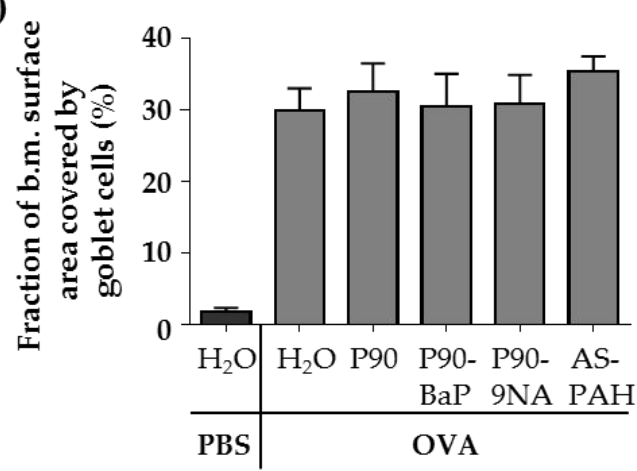

$\mathrm{OVA} / \mathrm{H}_{2} \mathrm{O}$

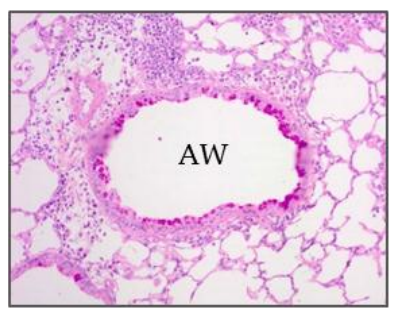

OVA/P90-9NA

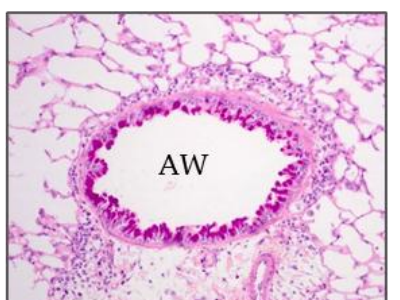

(c)

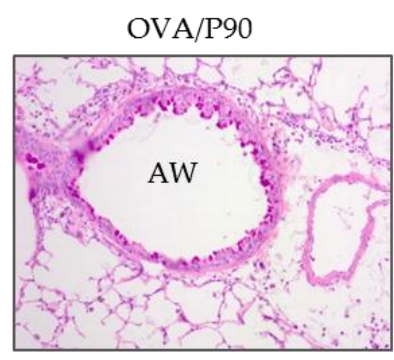

OVA/AS-PAH

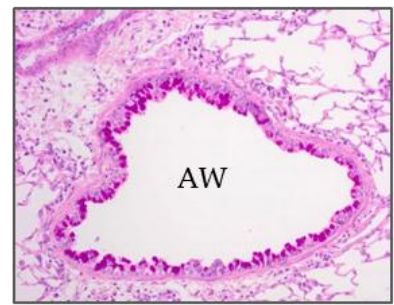

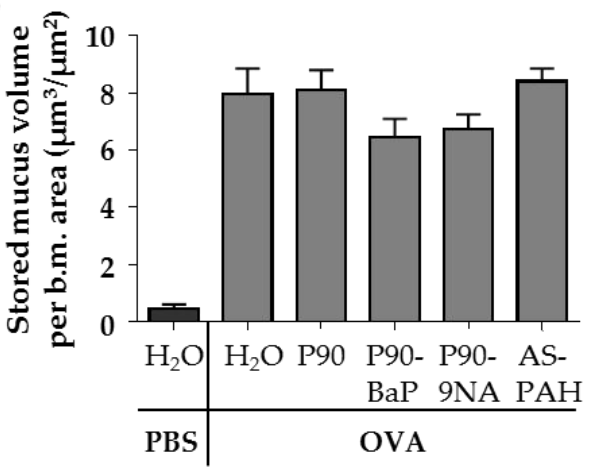

Figure 2. Cont. 
(d)

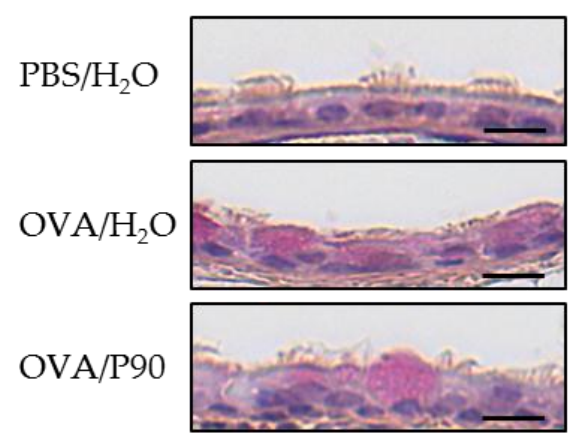

(e)

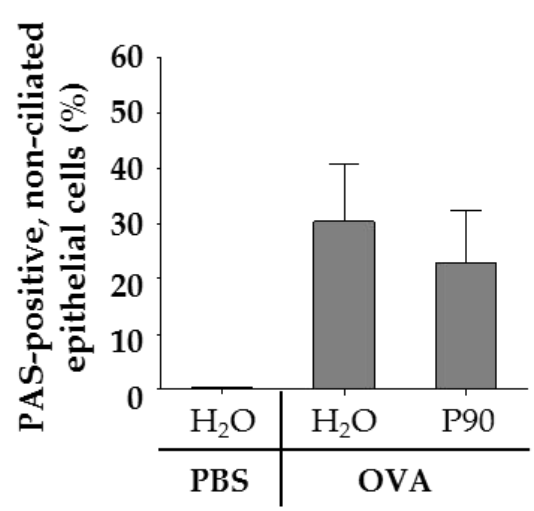

Figure 2. CBNP did not increase the number of PAS-positive cells in the airway epithelium. The images in (a) show the PAS-stained lung slices. PAS-positive cells are intensive pink and indicate mucus. AW means airway. Diagrams in (b) and (c) show the results of quantification, the fraction of the epithelial basement membrane (b.m.) surface area covered by goblet cells (b) and the stored mucus volume per b.m. area (c) $(n=7-8)$. The images in (d) show the PAS-stained tracheal epithelial cells. PAS-positive cells are pink and indicate mucus. The cell nuclei are blue (stained with hematoxylin). The quantification of PAS-positive non-ciliated cells is shown in (e) $(n=2-3)$.

\subsection{P90-Induced Mucus Release Affects the Ciliary Beat Frequency in Tracheal Epithelial Cells of OVA-Treated Mice}

To visualize the released mucus on the epithelium, we stained the mucus with fluorescent lectins in freshly explanted tracheae. The lectin staining showed increased mucus amounts on the epithelium of all OVA-treated mice (Figure 3a). However, the staining of mucus after exposure to P90 indicated an increased mucus quantity on the tracheal epithelium compared to the OVA controls (Figure 3a). Scanning electron microscopic images supported this finding, showing a mucus-covered epithelium after P90-exposure (Figure S3a).

Scanning electron microscopic images not only showed mucus on the tracheal epithelium after OVA treatment, but it also showed dead epithelial cells (Figure S3a). Since the mucus and the damaged epithelial cells can interfere with cilia-driven clearance in the airways, we analyzed the mean ciliary beat frequency and mean particle transport speed, and quantified the dead cells on the tracheal epithelium.

Compared to the PBS control group, the cilia-induced particle transport speed was decreased in the OVA controls (Figure 3b), whereas the ciliary beat frequency was not affected (Figure 3c), indicating that the mucus on the epithelium decelerated the transport speed. The exposure to the CBNP did not further decrease the particle transport (Figure 3b), but the ciliary beat frequency was decreased following exposure to P90 (Figure 3c).

To clarify whether this effect was due to a P90-triggered damage to the epithelial cells, we analyzed the dead epithelial cells in whole mount preparations of the trachea (Figure S3b). Generally, we detected no apoptotic cells in the whole mount preparations. However, the amount of necrotic epithelial cells was increased in the OVA control group compared to the PBS controls (Figure S3c). The exposure to CBNP, however, did not lead to a further increase in the number of necrotic epithelial cells (Figure S3c).

Due to these findings, we added adenosine triphosphate (ATP) to the trachea samples to assess the functionality of the cilia. After ATP-exposure, the ciliary beat frequency was equally increased in all test groups (Figure 3d) indicating that $\mathrm{P} 90$ did not induce a cilia damage.

Since the ciliary beat frequency directly correlates with the particle transport speed without mucus or dead cells on the epithelium, the particle transport speed was only increased in the PBS controls after ATP-exposure (Figure S4). In the trachea of OVA-treated mice (with or without exposure to 
CBNP), the increased ciliary beat frequency did not result in an increase of the particle transport speed (Figure S4), most likely due to the extensive amounts of mucus on the epithelium.

(a)
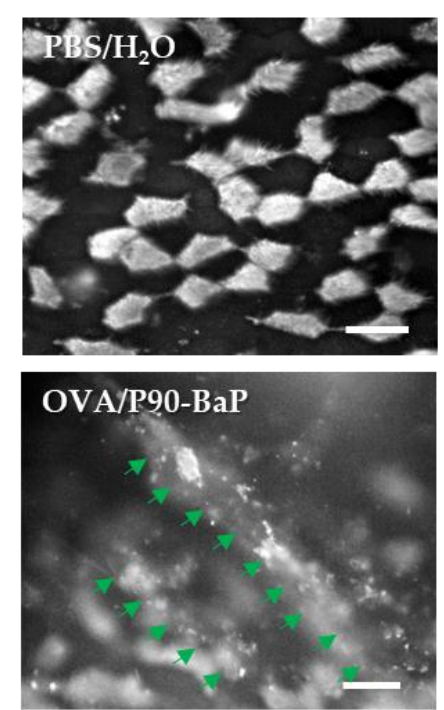

(b)

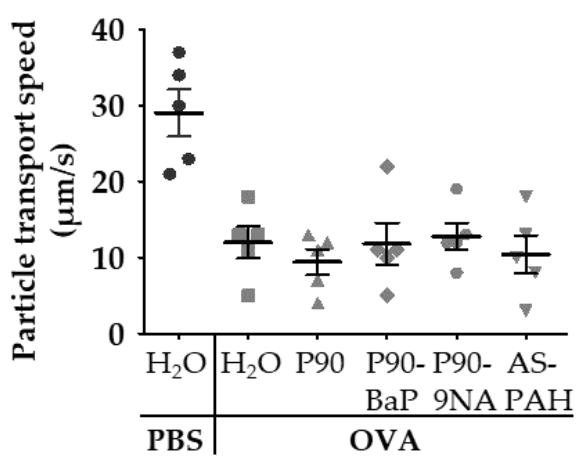

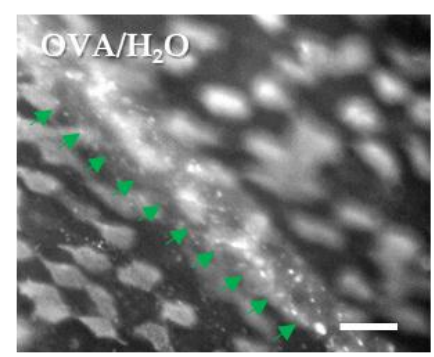

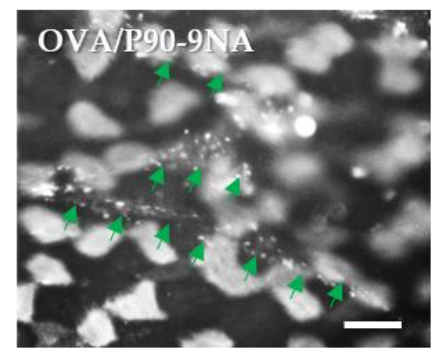

(c)

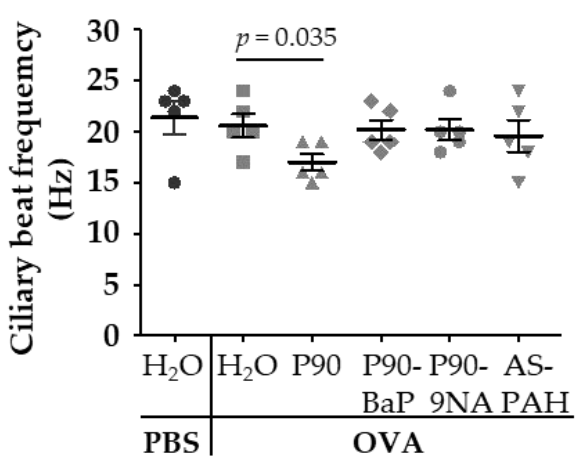

(d)

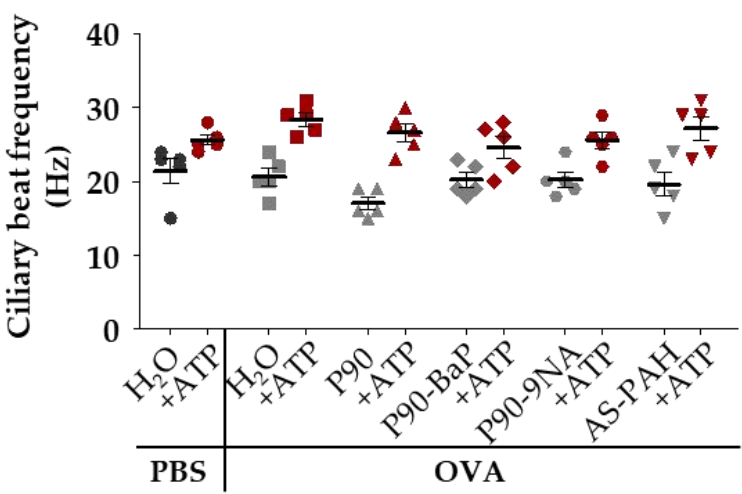

Figure 3. P90 aggravates the effects on mucociliary clearance in the trachea. The images in (a) show the mucus and ciliated cells (both are white) after staining with fluorescent lectins: Ulex europaeus agglutinin-1 and wheat germ agglutinin. The green arrows indicate mucus structures $(n=3)$. Diagrams in $(\mathbf{b}-\mathbf{d})$ show the results of the analysis of particle transport speed $(\mathbf{b})$ and the ciliary beat frequency $(\mathbf{c}, \mathbf{d})$ after exposure to CBNP. Every data point indicates a single experiment $(\mathbf{b}-\mathbf{d})$. The red symbols in (d) indicate the results of the stimulation with ATP. The mean ciliary beat frequency was calculated from at least 40 (c) and 30 (ATP stimulation in (d)) ciliated cells measured at four (c) or three (ATP stimulation in (d)) different tracheal regions of each animal. The lines with bars indicate the mean \pm SEM. 


\section{Discussion}

In a previous study, we showed that CBNP coated with PAH had only minor pro-inflammatory effects in healthy animals in vivo [21]. However, CBNP might exert different responses in individuals suffering from lung diseases, such as allergic asthma, and might result in the induction of an acute asthma exacerbation. In the present study, we showed that P90, with or without a defined surface-PAH and an acetylene soot with a mixture of surface $\mathrm{PAH}$, did not acutely aggravate the established allergic airway inflammation in mice. However, the unmodified P90 particles increased the mRNA expression of Muc5ac in tracheal epithelial cells, which is in agreement with the notion that a more adhesive and viscous Muc5ac-containing mucus is released [34].

In this study, we used P90 nanoparticles and coated the surface with a high-mutagenic 5-ring $\mathrm{PAH}$ (that is, benzo[a]pyrene, $\mathrm{BaP}$ ) or a low-mutagenic 3-ring PAH (that is, 9-nitroanthracene, 9NA). Since the particle characteristics, such as the particle size and surface properties, define the cytotoxic potential of particles [35], we analyzed the particle characteristics under dry conditions and in aqueous suspension. As also previously described in Reference [21], all P90-based nanoparticles have a similar mean primary particle size in the dry state and a similar hydrodynamic diameter and $\zeta$-potential in water with $0.5 \%$ BSA. However, due to the coating procedure, the specific surface area of the coated P90 particles is only approximately one-third of the surface area of unmodified P90 particles. The content of $\mathrm{PAH}$ on the $\mathrm{P} 90$ surface was $10 \% \mathrm{BaP}$ (P90-BaP) or $14 \%$ 9NA (P90-9NA) of the total particle mass. The similar PAH content and specific surface area of coated P90 particles allowed us to analyze the PAH-specific effects on the airway epithelial cells.

Additionally, we tested soot from acetylene combustion (AS-PAH) that reflects carbon-based nanoparticles from naturally occurring combustion processes. Compared to the coated P90 nanoparticles, the AS-PAH had similar particle characteristics regarding particle size, hydrodynamic diameter, and $\zeta$-potential. However, AS-PAH contains a mixture of at least $12 \mathrm{PAH}$ species on the surface with 2 to 5 aromatic rings. We identified the PAH acenaphthylene, which contains 3 aromatic rings, as the most abundant and the PAH cyclopenta[cd]pyrene, which consists of 5 aromatic rings, as the most toxic. Compared to the 5-ring PAH BaP, cyclopenta[cd]pyrene induces the same mutation mechanism [36] and is more tumorigenic in mouse studies [37]. However, based on the identified PAH species on the AS-PAH surface and our previous findings [21], the AS-PAH is potentially the most toxic nanoparticle tested in this study.

To avoid unrealistically high CBNP concentrations, we calculated a CBNP dose based on studies that determined the $\mathrm{PM}_{2.5}$ concentration in the ambient air of several cities in Europe and Asia [38-44]. In European cities, the mean annual concentration of $\mathrm{PM}_{2.5}$ fraction is low and ranged between $7 \mu \mathrm{g} / \mathrm{m}^{3}$ and $35 \mu \mathrm{g} / \mathrm{m}^{3}$ in the last few years [38-42]. However, the $\mathrm{PM}_{2.5}$ fraction can be temporally increased-for example, in congested roads-up to $76 \mu \mathrm{g} / \mathrm{m}^{3}$ [13]. In Chinese cities, the mean annual concentration of $\mathrm{PM}_{2.5}$ is higher and ranged from $55 \mu \mathrm{g} / \mathrm{m}^{3}$ to $102 \mu \mathrm{g} / \mathrm{m}^{3}$ in 2013 [43,44]. Moreover, the temporary peak concentrations can reach levels over $600 \mu \mathrm{g} / \mathrm{m}^{3}$ in urban areas $[45,46]$.

For our calculation, we used the data given by the Mouse Phenome Database for female Balb/c mice [47], that is, a minute volume of $98 \mathrm{~mL} / \mathrm{min}$ results in an inhaled amount of approximately 140 liters air/day. At a concentration of $50 \mu \mathrm{g} / \mathrm{m}^{3}$, a mouse inhales approximately $7 \mu \mathrm{g} \mathrm{PM}_{2.5} /$ day. Regarding the deposition efficiency of inhaled ultrafine particles in Balb/c mice and human lungs, only $40-50 \%$ of inhaled particles (in our case, $2.8 \mu \mathrm{g}-3.5 \mu \mathrm{g} \mathrm{PM}_{2.5}$ ) were deposited in the lungs [48,49].

At the dose of $7 \mu \mathrm{g}$ used in this study, the CBNP did not induce an acute increase of inflammation in the lungs or related parameters in the intrapulmonary airways or tracheal epithelial cells. This result is in agreement with the findings of a clinical double-blinded randomized cross-over pilot study that also found no acute effects on the allergic inflammation in human lungs after exposure to CBNP [50]. However, the authors suggested a long-term effect of CBNP on the course of the asthmatic disease, as described for P90 nanoparticles in an allergen (OVA) asthma mouse model [25]. The results obtained from the mouse model showed that the time point of P90-exposure determines the acute effect on inflammation and the course of the inflammatory response. If mice received the P90 nanoparticles $24 \mathrm{~h}$ 
before the allergen challenge and thus, before the establishment of an allergic airway inflammation, the acute inflammatory response to allergen-exposure was pronounced [25]. In contrast, if mice received the P90 nanoparticles $24 \mathrm{~h}$ after the establishment of an allergic airway inflammation, the inflammatory infiltrates were initially decreased and exhibited a temporally delayed increase after seven days [25].

In our study, we did not detect an increase or a decrease in immune cell numbers after exposure to P90 nanoparticles. Since we used a more distinctive asthma model with pronounced eosinophilia that indicated a present inflammation, and a repeated CBNP-exposure, immediately before and $24 \mathrm{~h}$ after the last OVA challenge, our more complex stimulation strategy may contribute to these differences.

Because we previously demonstrate that the response of lungs and tissues of healthy animals depends on the specific surface chemistry (that is, PAH) of the CBNP [21], we tested if the same holds true for animals suffering from an inflammatory lung disease such as asthma. We found that in contrast to P90, P90-BaP and P90-9NA decreased the numbers of eosinophils in the lungs, indicating that the coating might contribute to the previously described long-term effects on the course of allergic asthma diseases [25].

Immune and epithelial cells of the lung can respond to inhaled substances by the release of central mediators of asthma, such as IL-4 and IL-13 [51], as well as inflammatory mediators, such as IL-1 $\beta$ [52], and immune cell attracting proteins, such as Mcp-1 [53]. The profile of the mediators released depends on the inhaled substance and can be detected in the BAL fluid. In our study, the profile of inflammatory mediators was differentially regulated by the CBNP. The P90 nanoparticles decreased the protein level of IL-13, P90-BaP reduced the protein level of IL-4, P90-9NA induced the decrease of IL-1 $\beta$ and IL-13, and AS-PAH decreased the protein levels of IL-4 and IL-1 $\beta$. Since AS-PAH contained a PAH-mixture with 3-ring and 5-ring PAH and decreased IL-4 like P90-BaP-which is coated with the 5-ring PAH $\mathrm{BaP}$-and IL-1 $\beta$ like P90-9NA—which is coated with the 3-ring PAH 9NA-we suggest that the modulation of inflammation depends on the chemistry of the surface PAH. However, the decreased levels of the Mcp-1 protein after exposure to all CBNP, including the uncoated P90 particles, suggest that the general particle characteristics such as the particle size or the $\zeta$-potential contribute to the modulatory effect. In summary, our data indicate that the tested CBNP attenuate the allergic airway inflammation in mice. Although this response seems to be beneficial at first sight, it must be taken into account that this modulation of the immune response may affect the following reactions to allergens, leading to the worsening of asthmatic diseases [25].

Previous studies indicated that a lowered antioxidant defense may be responsible for the increased susceptibility to CBNP and CBNP-induced acute exacerbations of allergic airway inflammation [24,54]. However, our results did not confirm these reports. Although the antioxidant enzyme Gpx-3 had a decreased mRNA level after the OVA challenge, neither P90 nor the PAH-containing CBNP (P90-BaP, P90-9NA, or AS-PAH) induced the mRNA expression of cytokines or chemokines in the tracheal epithelial cells. Moreover, the CBNP also did not exacerbate the inflammatory response in the intrapulmonary airways. Only P90-9NA showed modulatory effects, decreasing the mRNA expression of the inflammatory mediator IL-6 and, consistent with the decreased IL-13 protein levels in the BAL fluid, of IL-13.

Besides airway inflammation, the increase of mucus secretion from goblet cells is a main feature of the acute asthmatic response. Indeed, mucus plugging was suggested to be a major factor responsible for the reduced lung function in severe asthmatics [55]. Mucus can be stained in the goblet cells with periodic acid-Schiff (PAS) reagent. The periodic acid oxidizes the carbohydrates on mucins, mainly Muc5ac, producing aldehyde groups that condense with the Schiff's reagent and result in a magenta coloration. Several studies showed that CBNP can increase the number of PAS-positive goblet cells in the airway epithelium in allergen (OVA) treated mice $[25,27,28,56]$, indicating an increased amount and release of mucus. In our present study, we did not find increased numbers of PAS-positive goblet cells or an increased volume of stored mucus in the airway epithelium after exposure to the CBNP. 
However, the main gel-forming mucins in mammals are Muc5ac and Muc5b [34]. Muc5b has physiologic functions, ensuring normal mucus clearance, whereas Muc5ac plays a role in mechanisms of allergen-induced airway hyperresponsiveness, mucous metaplasia, and airway mucus plugging [57-59]. After exposure to unmodified P90 nanoparticles, we detected an increase of the Muc5ac at the mRNA level in the tracheal epithelial cells compared to the OVA $/ \mathrm{H}_{2} \mathrm{O}$ group. In asthma, it is known that Muc5ac-rich mucus impairs the cilia-driven transport by epithelial tethering without defects in the cilia function [60]. Based on our results, we suggest that the further increase of Muc5ac induced by P90 nanoparticles modified the composition and characteristics of the released mucus. The resulting more adhesive and viscous mucus might have agglutinated the cilia, causing the observed decrease in the ciliary beat frequency. Since the PAH-coated P90 particles and the AS-PAH did not increase the mRNA expression of Muc5ac and did not affect the ciliary beat frequency, the higher specific surface area of P90 nanoparticles might be the critical particle characteristic responsible for this epithelial response.

Our results additionally revealed an airway-region specific response to P90. While the Muc5ac mRNA expression was increased in the tracheal epithelial cells, the Muc5ac mRNA levels in the intrapulmonary airways remained constant. In contrast, P90 decreased the mRNA expression of Muc5b in the intrapulmonary airways but had no effect on Muc5b mRNA level in the tracheal epithelial cells. As mentioned above, Muc5b, besides Muc5ac, is the main mucus-forming protein in the airways. Muc $5 b$ is required for the airway defense against pathogens and is important for effective mucociliary clearance $[57,61]$. Our results indicate that the proportion of Muc5ac and Muc5b is affected due to the P90-induced decrease of Muc5b mRNA expression in the intrapulmonary airways, probably affecting the mucociliary clearance. Since the decrease of the Muc5b expression is predicted to create an environment that promotes eosinophil survival [59] and, furthermore, the reduced Muc5b expression is a feature of severe (Th2-high) asthma [62], the P90-induced reduction of Muc5b mRNA levels also potentially indicates the worsening of allergic airway inflammation.

Since we administered the CBNP during an acute asthmatic response with extensive mucus release, the hydrophilic and lipophilic features of the CBNP may play a role in bioavailability [63]. The hydrophilic property of P90 may help the particles to penetrate into the mucus layer and facilitate the contact with the airway epithelium. In contrast, the lipophilic features of PAH bound on the surface of P90 particles and AS-PAH could facilitate the contact to glycoproteins and lipids in the mucus, leading to reduced bioavailability [63].

In conclusion, our results demonstrate that a relatively low dose of CBNP with or without PAH on the surface did not acutely aggravate the allergic airway inflammation in a mouse model of experimental allergic asthma. However, the PAH coating changed the biologic effect of CBNP on immune reaction and airway epithelial cells in vivo.

\section{Materials and Methods}

\subsection{Particle Preparation and Characterization}

Printex ${ }^{\circledR} 90$ (P90) was used as a reference CBNP. The surface was modified with benzo[a]pyrene (BaP) or 9-nitroanthracene (9NA). Additionally, we used soot obtained by acetylene combustion that contained a mixture of $\mathrm{PAH}$ on the surface. The coating procedure, the production of acetylene soot, and the methods of CBNP characterization are previously described in Reference [21].

\subsection{Preparation and Characterization of CBNP Suspension}

The administered CBNP suspensions had a concentration of $100 \mu \mathrm{g} / \mathrm{mL}$, prepared with a $10 \mathrm{mg}$ CBNP sample and $100 \mathrm{~mL}$ of double-deionized water. For suspension stability, $500 \mathrm{mg}$ of bovine serum albumin (BSA) (AppliChem Inc., Maryland Heights, MO, USA) was added. The suspensions were homogenized with an ultrasonic homogenizer as previously described in Reference [21]. The CBNP suspensions were used for experiments if no endotoxin was detectable using the CROMO-LAL assay (Associates of Cape Cod Inc., East Falmouth, MA, USA) following the manufacturer's protocol. 
The particle size and $\zeta$-potential were measured with a Malvern Zetasizer Nano-ZS (Malvern Instruments Ltd., Worcestershire, UK) at room temperature. The results are presented as mean \pm SEM.

\subsection{Animals}

Female 7-9 weeks old Balb/c mice (Charles River Laboratories, Sulzfeld, Germany) were housed under standard conditions. The mice received an OVA-free diet and water ad libitum. The in vivo studies were approved by the Ministerium für Energiewende, Landwirtschaft, Umwelt und ländliche Räume des Landes Schleswig-Holstein (V242-7224.122-1 (13-1/15) and V244-7224.121.3 (12-1/15)).

\subsection{Animal Treatment Protocol}

The experimental allergic asthma model was previously described in Reference [64]. The mice were sensitized to ovalbumin (OVA; albumin from chicken egg white, Grade VI; Sigma-Aldrich Chemie $\mathrm{GmbH}$, Munich, Germany) by three intraperitoneal (i.p.) injections of OVA adsorbed to aluminium hydroxide (Imject ${ }^{\mathrm{TM}}$ Alum Adjuvant, Thermo Scientific Inc., Pierce Biotechnology, Rockford, IL, USA) on day 1,14 , and 21 . The control group received $200 \mu \mathrm{L}$ Dulbecco's phosphate-buffered saline i.p. (D-PBS; Sigma-Aldrich Chemie GmbH, Munich, Germany). On day 26, 27, and 28, the animals were exposed to an OVA (Grade V; Sigma-Aldrich Chemie GmbH, Munich, Germany) aerosol ( $1 \%$ w/v in PBS). The oropharyngeal application of CBNP suspension was performed on day 28 before the last challenge and on day 29. For this procedure, the mice were anesthetized with isoflurane and received $70 \mu \mathrm{L}$ of CBNP dissolved in sterile water (100 $\mu \mathrm{g}$ CBNP/mL water) or only water as a control. On day 30 , the mice were euthanized and the body and lung weight was determined.

\subsection{Differential Cell Count in Bronchoalveolar Lavage (BAL) Fluid}

Before explantation of airways or trachea, the trachea was cannulated and the lungs were rinsed with $1 \mathrm{~mL}$ D-PBS (Sigma-Aldrich Chemie GmbH, Munich, Germany) containing a protease inhibitor (Complete, Roche, Basel, Switzerland). The volume of BAL fluid was recorded and the number of immune cells was determined using a Neubauer counting chamber. For differential cell count, $50 \mu \mathrm{L}$ of BAL fluid was cytospinned ( $500 \times g, 5$ min; Cytospin ${ }^{\mathrm{TM}}$, Thermo Scientific GmbH, Schwerte, Germany) and the immune cells (macrophages, lymphocytes, eosinophil and neutrophil granulocytes) were stained using the Pappenheim method or the Diffquick solutions (Medion Grifols Diagnostics AG, Düdingen, Switzerland). A total number of at least 100 immune cells was counted. The results are presented as the total number of macrophages, eosinophils, neutrophils and lymphocytes per $\mathrm{mL}$ BAL fluid.

\subsection{Preparation of Airways}

The tracheae were explanted, transferred to culture dishes that was coated with a thin layer of Sylgard ${ }^{\circledR} 184$ Silicone Elastomer (Dow Corning GmbH, Wiesbaden, Germany), and filled with HEPES-buffered Ringer solution. The tracheae were fixed on the dish bottom with insect needles and prepared for the isolation of epithelial cells and, following RNA isolation, for mucus staining and functional experiments. The distal airways were microdissected from the surrounding parenchyma under a stereomicroscope and pooled for RNA experiments [65].

\subsection{RNA Isolation and Quantitative RT-PCR}

The isolation of the total RNA from isolated tracheal epithelial cells and dissected distal airways, the used reagents for DNA digestion and reverse transcription, and the PCR conditions are previously described in Reference [21].

For the determination of the mRNA expression levels in tracheal epithelial cells, the real-time RT-PCR was performed in TaqMan Universal PCR Master Mix (Life Technologies GmbH, Darmstadt, Germany) using the ABI PRISM 7900HT or StepOnePlus ${ }^{\mathrm{TM}}$ Sequence Detector System (both Applied 
Biosystems, Foster City, CA, USA). The probes were tagged with reporter 6-FAM and quencher Tamra. Changes of the mRNA expression were determined by calculating the difference in the cycle threshold to the housekeeping gene RPL32 with the $\Delta \Delta C_{T}$ method and represented as an n-fold expression $\left(2^{-\Delta \Delta C} \mathrm{~T}\right)$.

To analyze the changes in the transcript levels in distal airways, the real-time RT-PCR was performed on a Roche Light Cycler 480 II Instrument (Roche Diagnostics Deutschland GmbH, Mannheim, Germany) using Light Cycler 480 SYBR green I Master (Roche Diagnostics Deutschland $\mathrm{GmbH}$ ) according to the manufacturer's protocol. The PCR cycling conditions were as follows: one cycle at $95^{\circ} \mathrm{C}$ for $10 \mathrm{~min}$ followed by 45 cycles touch-down $63^{\circ} \mathrm{C}-58^{\circ} \mathrm{C}$ for $8 \mathrm{~s}$ with $0.5^{\circ} \mathrm{C} / \mathrm{s}$ and $72{ }^{\circ} \mathrm{C}$ for $10 \mathrm{~s}$. Changes in mRNA expression were determined by calculating the $\mathrm{n}$-fold difference in the cycle threshold to the housekeeping gene RPL32 by normalization using the rule of proportion.

The probes and primers used for quantitative real-hypertime RT-PCR are shown in Table S2.

\subsection{Measurement of the Protein Levels in the BAL Fluid}

After centrifugation of the BAL fluid, cytokines and chemokines relevant for lung inflammation were determined in the supernatant by using a Cytometric bead array (CBA Flex Set Kits; BD Bioscience, San Jose, CA, USA) according to the manufacturer's protocol. The fluorescent intensity was analyzed on a BD Accuri ${ }^{\mathrm{TM}} \mathrm{C} 6$ flow cytometer (BD Bioscience, San Jose, CA, USA). The analysis was performed using the FCAP Array ${ }^{\mathrm{TM}}$ v3.0 Software (BD Bioscience, San Jose, CA, USA). The results are presented as absolute protein concentrations $(\mathrm{pg} / \mathrm{mL})$.

\subsection{PAS Staining}

The lungs were fixed ex situ by the intra-tracheal instillation of a $4 \%(w / v)$ phosphate buffered paraformaldehyde. Afterwards, the lungs were removed, stored in $4 \%$ paraformaldehyde overnight, and embedded in paraffin. The orientation of the lungs was randomized according to the orientator technique [66]. In order to quantify the goblet cells and stored mucus in the airway epithelium, $2 \mu \mathrm{m}$ thick lung sections were stained with periodic acid-Schiff (PAS) reagent. Images were recorded using a microscope (BX-51; Olympus, Tokyo, Japan) equipped with a digital camera (DP-25; Olympus, Tokyo, Japan) at 20-fold magnification. The surface area of the mucin-containing goblet cells $\left(S_{\mathrm{gc}}\right)$ per total surface area of airway epithelial basal membrane $\left(S_{\mathrm{ep}}\right)$ and the volume of the PAS-stained epithelial mucin $\left(V_{\text {mucin }}\right)$ per $S_{\text {ep }}$ were determined using a computer-assisted stereology toolbox (newCAST, Visiopharm, Hoersholm, Denmark) that was previously described in Reference [67]. $S_{\mathrm{gc}}$, $S_{\text {ep }}$, and $V_{\text {mucin }}$ were calculated according to the formulas: $S_{g c} / S_{e p}=\sum I_{g c} / \sum I_{e p}$ and $V_{m u c i n} / S_{e p}=$ $L P \times \sum P_{\text {mucin }} / 2 \times \sum I_{e p}$, where $I_{g c}$ is the interaction of the test line with the goblet cells, $I_{e p}$ is the interaction of the test line with the epithelial basal membrane, $P_{\text {mucin }}$ is the point hitting mucin, and LP is the test line length at final magnification.

Trachea samples were explanted, pinned on a cork plate, and fixed in $4 \%$ phosphate-buffered paraformaldehyde. The trachea samples were embedded in paraffin and longitudinally sliced in fractionated series. The $7 \mu \mathrm{m}$ thick sections were stained via PAS reaction and Hematoxylin. The PAS-positive cells were counted in a minimum of 2 different areas with a distance of $490 \mu \mathrm{m}$. The areas had a minimum width of $350 \mu \mathrm{m}$ analyzing a slice every $70 \mu \mathrm{m}$. A minimum of 520 total epithelial cells was counted in the areas, respectively. The amount of PAS-positive cells is presented as the percentage of the total number of non-ciliated cells.

\subsection{Mucus Staining on the Vital Tracheal Epithelium}

The tracheae were incubated in $1 \mathrm{~mL}$ of HEPES-buffered Ringer solution at $30^{\circ} \mathrm{C}$. Next, $0.5 \mu \mathrm{L}$ of wheat germ agglutinin (WGA) and Ulex europaeus agglutinin both labeled with Alexa Fluor ${ }^{\circledR} 555$ (both $1 \mu \mathrm{g} / \mathrm{mL}$; Molecular Probes Inc., Eugene, OR, USA) were added. Both lectins stain carbohydrate residues present in mucins $[68,69]$ and WGA also stains cilia [70]. The staining was imaged with 
a Zeiss Examiner.D1 microscope equipped with an AxioMR camera and an Achroplan $40 \times / 0.8 \mathrm{~W}$ objective (Carl Zeiss MicroImaging GmbH, Göttingen, Germany).

\subsection{Whole Mount Analysis of Dead Cells}

The whole mount samples of the tracheae were incubated in a pre-warmed HEPES-buffer Ringer solution. Ethidium homodimer-1 (1 $\mu \mathrm{g} / \mathrm{mL}$; Life Technologies GmbH, Darmstadt, Germany) that stains necrotic cells was added and the trachea samples were incubated for $30 \mathrm{~min}$ at $37^{\circ} \mathrm{C}$. The samples were fixed with a $4 \%$ paraformaldehyde ( $\mathrm{pH} 7.4$ ), washed with PBS ( $\mathrm{pH} 7.4$ ), and permeabilized with ice-cold acetone. The samples were incubated with two antibodies overnight at room temperature, a rabbit monoclonal anti-cleaved caspase-3 antibody (Clone 5A1E, dilution 1:200, Cell Signaling Technology Inc., Danvers, MA, USA) that was labeled with Atto488 (Lightning-Link ${ }^{\mathrm{TM}}$ Atto488 conjugation kit; Innova Bioscience Ltd., Cambridge, UK), and a mouse monoclonal anti-acetylated $\alpha$-tubulin antibody (Clone 6-11B-1, dilution 1:200; Sigma-Aldrich GmbH, Steinheim, Germany) that was labeled with Atto647 (Lightning-Link ${ }^{\mathrm{TM}}$ Atto647 conjugation kit; Innova Bioscience Ltd., Cambridge, UK). After washing with PBS (pH 7.4), the whole mount preparations were incubated with Hoechst $33258(1 \mu \mathrm{g} / \mathrm{mL}$; Sigma Aldrich, Steinheim, Germany) for $1 \mathrm{~h}$ at room temperature. Next, the trachea samples were washed again with PBS (pH 7.4) and covered with Mowiol mounting medium. The anti-cleaved caspase- 3 antibody labels apoptotic cells and the anti-acetylated $\alpha$-tubulin antibody labels cilia for the identification of the epithelial layer. Cell nuclei were stained with Hoechst 33258. Apoptotic and necrotic epithelial cells were localized using a confocal laser scanning microscope (LSM 710; Carl Zeiss MicroImaging GmbH, Göttingen, Germany) equipped with a Plan-Neofluor $40 \times / 1.30$ oil DIC objective. A minimum of 2700 epithelial cells was counted in the complete whole mount preparation. The results are presented as a percentage of the total cell numbers.

\subsection{Particle Transport Speed and Ciliary Beat Frequency}

Trachea samples were transferred to a Delta T4 Culture dish (Bioptechs Inc., Butler, PA, USA) whose bottom was covered with a Sylgard ${ }^{\circledR} 184$ Silicone Elastomer. The samples were fixed on the bottom with the epithelium facing upwards and covered with $2 \mathrm{~mL}$ of HEPES-Ringer solution. The incubation temperature was maintained at $30^{\circ} \mathrm{C}$ using a Bioptechs Delta T4 Culture Dish Controller (Bioptechs Inc., Butler, PA, USA). The particle transport and the cilia beating were imaged using a Zeiss Examiner.D1 microscope equipped with an Achroplan $40 \times / 0.80 \mathrm{~W}$ or $20 \times / 1.0$ DIC (UV) VIS-R objectives (Carl Zeiss MicroImaging GmbH, Göttingen, Germany). The transport of $4.5 \mu \mathrm{m}$ polystyrene particles $\left(2 \times 10^{6}\right.$ particles $\left./ \mathrm{mL}\right)$ and the cilia motion were recorded with an SMX-150M camera (EHD Imaging $\mathrm{GmbH}$, Damme, Germany).

Particle transport was recorded with 200 images at a frame rate of $12 \mathrm{~Hz}$ from at least four different areas for each trachea. The particle transport speed was determined using Image-Pro ${ }^{\circledR}$ Plus 6.0 (Medium Cybernetics, Inc., Bethesda, MD, USA) and the mean particle transport speed was calculated for each analyzed trachea.

The cilia motion was recorded with 1000 images at a $100 \mathrm{~Hz}$ frame rate in at least four different areas for each trachea. The ciliary beat frequency of 10 ciliated cells was measured in every area. The ciliary beat frequency was determined by Fourier transformation of grey level changes over time using a Mathlab-based software (Mathworks, Natick, MA, USA) and the mean frequency was calculated for each trachea. To activate cilia beating, adenosine triphosphate (ATP, $10 \mu \mathrm{M}$ ) was added at the end of each experiment.

\subsection{Assessment of Airway Responsiveness to Methacholine}

The airway responsiveness to methacholine (MCh) was invasively assessed by measurement of the total lung resistance using Finepoint RC Units (Data Science International, New Brighton, MN, USA). The mice were anesthetized, tracheotomized with a cannula, and mechanically ventilated as 
previously described in Reference [33]. The data represent the airway resistance in response to a $100 \mathrm{mg} / \mathrm{mL}$ MCh dose.

\subsection{Preparation of Trachea Samples for Scanning Electron Microscopy}

After fixation in the Monti-Graziadei solution ( $\mathrm{pH}$ 3.5) [71], the trachea samples were washed with $0.1 \mathrm{M}$ sodium cacodylate buffer ( $\mathrm{pH}$ 7.4) and subjected to critical-point drying. The dried samples were sputtered with platinum (Polaron SEM coating system, Polaron Instruments, Lewes, UK) and the tracheal epithelium was investigated using a scanning electron microscope (EVO HD15, Zeiss, Oberkochen, Germany).

\subsection{Statistical Analysis}

The data are presented as mean \pm SEM. All experiments were carried out at least three times. The results were analyzed using the Mann-Whitney U test in GraphPad Prism (GraphPad Software, Inc., La Jolla, CA, USA). $p$-values $<0.05$ were considered statistically significant.

Supplementary Materials: The following are available online at http://www.mdpi.com/2079-4991/8/4/213/s1: Figure S1: Particle characteristics of P90-BaP and AS-PAH used in the present study. Figure S2: Carbon Black nanoparticle (CBNP)-exposure did not increase the lung wet weight in ovalbumin (OVA)-treated mice. Figure S3: CBNP did not increase the number of necrotic cells in the tracheal epithelium of OVA-treated mice. Figure S4: ATP did not increase the particle transport speed on the tracheal epithelium of OVA- and CBNP-treated mice. Table S1: The identified surface-bound polycyclic aromatic hydrocarbon (PAH) species of AS-PAH. Table S2: The primer and probe sequences used for quantitative polymerase chain reaction (PCR).

Acknowledgments: This study was funded by the Bundesministerium für Bildung und Forschung (03X0153). The authors thank Kathy Budler, Gudrun Knebel, Harry Manfeldt, Petra Lau (Lübeck), Ines Voepel (Hannover), and Juliane Artelt (Borstel) for their expert technical assistance.

Author Contributions: P.K. and H.F. conceived and designed the experiments. S.W. and K.L. performed the experiments and analyzed the data. M.S. and H.B. produced and analyzed the particles. T.H. provided the CBNP suspensions and analyzed the CBNP characteristics in suspension. K.L., S.W., H.F., and P.K. wrote the manuscript.

Conflicts of Interest: The authors declare no conflict of interest.

\section{References}

1. Global Burden of Disease Study 2013 Collaborators. Global, regional, and national incidence, prevalence, and years lived with disability for 301 acute and chronic diseases and injuries in 188 countries, 1990-2013: A systematic analysis for the Global Burden of Disease Study 2013. Lancet 2015, 386, 743-800.

2. Fanta, C.H. Asthma. N. Engl. J. Med. 2009, 360, 1002-1014. [CrossRef] [PubMed]

3. Fahy, J.V.; Dickey, B.F. Airway mucus function and dysfunction. N. Engl. J. Med. 2010, 363, $2233-2247$. [CrossRef] [PubMed]

4. Munkholm, M.; Mortensen, J. Mucociliary clearance: Pathophysiological aspects. Clin. Physiol. Funct. Imaging 2014, 34, 171-177. [CrossRef] [PubMed]

5. Wardlaw, A.J.; Brightling, C.E.; Green, R.; Woltmann, G.; Bradding, P.; Pavord, I.D. New insights into the relationship between airway inflammation and asthma. Clin. Sci. 2002, 103, 201-211. [CrossRef] [PubMed]

6. Brightling, C.E.; Symon, F.A.; Birring, S.S.; Bradding, P.; Pavord, I.D.; Wardlaw, A.J. TH2 cytokine expression in bronchoalveolar lavage fluid $\mathrm{T}$ lymphocytes and bronchial submucosa is a feature of asthma and eosinophilic bronchitis. J. Allergy Clin. Immunol. 2002, 110, 899-905. [CrossRef] [PubMed]

7. James, A.L.; Wenzel, S. Clinical relevance of airway remodelling in airway diseases. Eur. Respir. J. 2007, 30, 134-155. [CrossRef] [PubMed]

8. Bergeron, C.; Tulic, M.K.; Hamid, Q. Airway remodelling in asthma: From benchside to clinical practice. Can. Respir J. 2010, 17, e85-e93. [CrossRef] [PubMed]

9. Jackson, D.J.; Sykes, A.; Mallia, P.; Johnston, S.L. Asthma exacerbations: Origin, effect, and prevention. J. Allergy Clin. Immunol. 2011, 128, 1165-1174. [CrossRef] [PubMed]

10. Guarnieri, M.; Balmes, J.R. Outdoor air pollution and asthma. Lancet 2014, 383, 1581-1592. [CrossRef] 
11. Weinmayr, G.; Romeo, E.; De Sario, M.; Weiland, S.K.; Forastiere, F. Short-term effects of $\mathrm{PM}_{10}$ and $\mathrm{NO}_{2}$ on respiratory health among children with asthma or asthma-like symptoms: A systematic review and meta-analysis. Environ. Health Perspect. 2010, 118, 449-457. [CrossRef] [PubMed]

12. Spira-Cohen, A.; Chen, L.C.; Kendall, M.; Lall, R.; Thurston, G.D. Personal exposures to traffic-related air pollution and acute respiratory health among Bronx schoolchildren with asthma. Environ. Health Perspect. 2011, 119, 559-565. [CrossRef] [PubMed]

13. McCreanor, J.; Cullinan, P.; Nieuwenhuijsen, M.J.; Stewart-Evans, J.; Malliarou, E.; Jarup, L.; Harrington, R.; Svartengren, M.; Han, I.; Ohman-Strickland, P.; et al. Respiratory effects of exposure to diesel traffic in persons with asthma. N. Engl. J. Med. 2007, 357, 2348-2358. [CrossRef] [PubMed]

14. von Klot, S.; Wolke, G.; Tuch, T.; Heinrich, J.; Dockery, D.W.; Schwartz, J.; Kreyling, W.G.; Wichmann, H.E.; Peters, A. Increased asthma medication use in association with ambient fine and ultrafine particles. Eur. Respir. J. 2002, 20, 691-702. [CrossRef] [PubMed]

15. Nordenhall, C.; Pourazar, J.; Ledin, M.C.; Levin, J.O.; Sandstrom, T.; Adelroth, E. Diesel exhaust enhances airway responsiveness in asthmatic subjects. Eur. Respir. J. 2001, 17, 909-915. [CrossRef] [PubMed]

16. Szewczynska, M.; Posniak, M.; Dobrzynska, E. Study on individual PAHs content in ultrafine particles from solid fractions of diesel and biodiesel exhaust fumes. J. Chem. 2013, 2013, 528471. [CrossRef]

17. Mabilia, R.; Cecinato, A.; Tomasi Sciano, M.C.; Di Palo, V.; Possanzini, M. Characterization of polycyclic aromatic hydrocarbons and carbonyl compounds in diesel exhaust emissions. Ann. Chim. 2004, 94, 733-740. [CrossRef] [PubMed]

18. Tobiszewski, M.; Namiesnik, J. PAH diagnostic ratios for the identification of pollution emission sources. Environ. Pollut. 2012, 162, 110-119. [CrossRef] [PubMed]

19. Ravindra, K.; Sokhi, R.; Van Grieken, R. Atmospheric polycyclic aromatic hydrocarbons: Source attribution, emission factors and regulation. Atmos. Environ. 2008, 42, 2895-2921. [CrossRef]

20. Moorthy, B.; Chu, C.; Carlin, D.J. Polycyclic aromatic hydrocarbons: From metabolism to lung cancer. Toxicol. Sci. 2015, 145, 5-15. [CrossRef] [PubMed]

21. Lindner, K.; Strobele, M.; Schlick, S.; Webering, S.; Jenckel, A.; Kopf, J.; Danov, O.; Sewald, K.; Buj, C.; Creutzenberg, O.; et al. Biological effects of carbon black nanoparticles are changed by surface coating with polycyclic aromatic hydrocarbons. Part. Fibre Toxicol. 2017, 14, 8. [CrossRef] [PubMed]

22. Eom, S.Y.; Yim, D.H.; Moon, S.I.; Youn, J.W.; Kwon, H.J.; Oh, H.C.; Yang, J.J.; Park, S.K.; Yoo, K.Y.; Kim, H.S.; et al. Polycyclic aromatic hydrocarbon-induced oxidative stress, antioxidant capacity, and the risk of lung cancer: A pilot nested case-control study. Anticancer Res. 2013, 33, 3089-3097. [PubMed]

23. Osgood, R.S.; Upham, B.L.; Hill, T., 3rd; Helms, K.L.; Velmurugan, K.; Babica, P.; Bauer, A.K. Polycyclic aromatic hydrocarbon-induced signaling events relevant to inflammation and tumorigenesis in lung cells are dependent on molecular structure. PLoS ONE 2014, 8, e65150. [CrossRef] [PubMed]

24. Alessandrini, F.; Beck-Speier, I.; Krappmann, D.; Weichenmeier, I.; Takenaka, S.; Karg, E.; Kloo, B.; Schulz, H.; Jakob, T.; Mempel, M.; et al. Role of oxidative stress in ultrafine particle-induced exacerbation of allergic lung inflammation. Am. J. Respir. Crit. Care Med. 2009, 179, 984-991. [CrossRef] [PubMed]

25. Alessandrini, F.; Schulz, H.; Takenaka, S.; Lentner, B.; Karg, E.; Behrendt, H.; Jakob, T. Effects of ultrafine carbon particle inhalation on allergic inflammation of the lung. J. Allergy Clin. Immunol. 2006, 117, 824-830. [CrossRef] [PubMed]

26. de Haar, C.; Hassing, I.; Bol, M.; Bleumink, R.; Pieters, R. Ultrafine carbon black particles cause early airway inflammation and have adjuvant activity in a mouse allergic airway disease model. Toxicol. Sci. 2005, 87, 409-418. [CrossRef] [PubMed]

27. Inoue, K.; Takano, H.; Yanagisawa, R.; Sakurai, M.; Ichinose, T.; Sadakane, K.; Yoshikawa, T. Effects of nano particles on antigen-related airway inflammation in mice. Respir. Res. 2005, 6, 106. [CrossRef] [PubMed]

28. Inoue, K.; Takano, H.; Yanagisawa, R.; Sakurai, M.; Abe, S.; Yoshino, S.; Yamaki, K.; Yoshikawa, T. Effects of nanoparticles on lung physiology in the presence or absence of antigen. Int. J. Immunopathol. Pharmacol. 2007, 20, 737-744. [CrossRef] [PubMed]

29. Kumar, P.; Morawska, L.; Birmili, W.; Paasonen, P.; Hu, M.; Kulmala, M.; Harrison, R.M.; Norford, L.; Britter, R. Ultrafine particles in cities. Environ. Int. 2014, 66, 1-10. [CrossRef] [PubMed]

30. Aranda, A.; Diaz-de-Mera, Y.; Notario, A.; Rodriguez, D.; Rodriguez, A. Fine and ultrafine particles in small cities. A case study in the south of Europe. Environ. Sci. Pollut. Res. Int. 2015, 22, 18477-18486. [CrossRef] [PubMed] 
31. Tsai, J.H.; Lai, W.F.; Chiang, H.L. Characteristics of particulate constituents and gas precursors during the episode and non-episode periods. J. Air Waste Manag. Assoc. 2013, 63, 27-40. [CrossRef] [PubMed]

32. Kyjovska, Z.O.; Jacobsen, N.R.; Saber, A.T.; Bengtson, S.; Jackson, P.; Wallin, H.; Vogel, U. DNA damage following pulmonary exposure by instillation to low doses of carbon black (Printex 90) nanoparticles in mice. Environ. Mol. Mutagen. 2015, 56, 41-49. [CrossRef] [PubMed]

33. Lunding, L.P.; Webering, S.; Vock, C.; Behrends, J.; Wagner, C.; Holscher, C.; Fehrenbach, H.; Wegmann, M. Poly(inosinic-cytidylic) acid-triggered exacerbation of experimental asthma depends on IL-17A produced by NK cells. J. Immunol. 2015, 194, 5615-5625. [CrossRef] [PubMed]

34. Bonser, L.R.; Erle, D.J. Airway Mucus and Asthma: The Role of MUC5AC and MUC5B. J. Clin. Med. 2017, 6, 112. [CrossRef] [PubMed]

35. Bakand, S.; Hayes, A.; Dechsakulthorn, F. Nanoparticles: A review of particle toxicology following inhalation exposure. Inhal. Toxicol. 2012, 24, 125-135. [CrossRef] [PubMed]

36. Keohavong, P.; Melacrinos, A.; Shukla, R. In vitro mutational spectrum of cyclopenta[cd]pyrene in the human HPRT gene. Carcinogenesis 1995, 16, 855-860. [CrossRef] [PubMed]

37. Nesnow, S.; Mass, M.J.; Ross, J.A.; Galati, A.J.; Lambert, G.R.; Gennings, C.; Carter, W.H., Jr.; Stoner, G.D. Lung tumorigenic interactions in strain A/J mice of five environmental polycyclic aromatic hydrocarbons. Environ. Health Perspect. 1998, 106 (Suppl. 6), 1337-1346. [CrossRef] [PubMed]

38. The Danish Environmental Protection Agency. Exposure to Nanomaterials from the Danish Environment; The Danish Environmental Protection Agency: København, Denmark, 2015; ISBN 978-87-93283-54-1.

39. Department for Environment, Food and Rural A. Air Pollution in the UK 2013. 2014. Available online: https:/ /uk-air.defra.gov.uk/assets / documents/annualreport/air_pollution_uk_2013_issue_1.pdf (accessed on 1 November 2014).

40. Netherlands Environmental Assessment Agency. PM 2.5 in the Netherlands-Consequences of the New European Air Quality Standards; MNP Report 50009901/2007; Netherlands Environmental Assessment Agency: The Hague, The Netherlands, 2007; ISBN 978-90-6960-176-2.

41. European Environment Agency. Air quality in Europe-2016 Report; EEA Report No 28/2016; European Environment Agency: Copenhagen, Denmark, 2016; ISBN 978-92-9213-847-9.

42. Guerreiro, C.B.B.; Foltescu, V.; de Leeuw, F. Air quality status and trends in Europe. Atmos. Environ. 2014, 98, 376-384. [CrossRef]

43. Lowsen, D.H.; Conway, G.A. Air Pollution in Major Chinese Cities: Some Progress, But Much More to Do. J. Environ. Prot. 2017, 7, 2081-2094. [CrossRef] [PubMed]

44. San Martini, F.M.; Hasenkopf, C.A.; Roberts, D.C. Statistical analysis of PM2.5 observations from diplomatic facilities in China. Atmos. Environ. 2015, 110, 174-185. [CrossRef]

45. Zhao, P.; Lin, C.-C. Air Quality at Night Markets in Taiwan. J. Air Waste Manag. Assoc. 2010, 60, 369-377. [CrossRef] [PubMed]

46. Han, X.; Naeher, L.P. A review of traffic-related air pollution exposure assessment studies in the developing world. Environ. Int. 2006, 32, 106-120. [CrossRef] [PubMed]

47. Mouse Phenome Database at The Jackson Laboratory. 2014. Available online: https://phenome.jax.org/ measureset/35101 (accessed on 1 October 2014).

48. Oldham, M.J.; Phalen, R.F.; Budiman, T. Comparison of predicted and experimentally measured aerosol deposition efficiency in BALB/c mice in a new nose-only exposure system. Aerosol. Sci. Technol. 2009, 43, 970-977. [CrossRef]

49. Möller, W.; Felten, K.; Sommerer, K.; Scheuch, G.; Meyer, G.; Meyer, P.; Haussinger, K.; Kreyling, W.G. Deposition, retention, and translocation of ultrafine particles from the central airways and lung periphery. Am. J. Respir. Crit. Care Med. 2008, 177, 426-432. [CrossRef] [PubMed]

50. Schaumann, F.; Fromke, C.; Dijkstra, D.; Alessandrini, F.; Windt, H.; Karg, E.; Muller, M.; Winkler, C.; Braun, A.; Koch, A.; et al. Effects of ultrafine particles on the allergic inflammation in the lung of asthmatics: Results of a double-blinded randomized cross-over clinical pilot study. Part. Fibre Toxicol. 2014, 11, 39. [CrossRef] [PubMed]

51. Gour, N.; Wills-Karp, M. IL-4 and IL-13 signaling in allergic airway disease. Cytokine 2015, 75, 68-78. [CrossRef] [PubMed]

52. Lopez-Castejon, G.; Brough, D. Understanding the mechanism of IL-1beta secretion. Cytokine Growth Factor Rev. 2011, 22, 189-195. [CrossRef] [PubMed] 
53. Alam, R.; York, J.; Boyars, M.; Stafford, S.; Grant, J.A.; Lee, J.; Forsythe, P.; Sim, T.; Ida, N. Increased MCP-1, RANTES, and MIP-1alpha in bronchoalveolar lavage fluid of allergic asthmatic patients. Am. J. Respir. Crit. Care Med. 1996, 153, 1398-1404. [CrossRef] [PubMed]

54. Sahiner, U.M.; Birben, E.; Erzurum, S.; Sackesen, C.; Kalayci, O. Oxidative stress in asthma. World Allergy Organ. J. 2011, 4, 151-158. [CrossRef] [PubMed]

55. Dunican, E.M.; Elicker, B.M.; Gierada, D.S.; Nagle, S.K.; Schiebler, M.L.; Newell, J.D.; Raymond, W.W.; Lachowicz-Scroggins, M.E.; Di Maio, S.; Hoffman, E.A.; et al. Mucus plugs in patients with asthma linked to eosinophilia and airflow obstruction. J. Clin. Investig. 2018, 128, 997-1009. [CrossRef] [PubMed]

56. Inoue, K. Promoting effects of nanoparticles/materials on sensitive lung inflammatory diseases. Environ. Health Prev. Med. 2011, 16, 139-143. [CrossRef] [PubMed]

57. Roy, M.G.; Livraghi-Butrico, A.; Fletcher, A.A.; McElwee, M.M.; Evans, S.E.; Boerner, R.M.; Alexander, S.N.; Bellinghausen, L.K.; Song, A.S.; Petrova, Y.M.; et al. Muc5b is required for airway defence. Nature 2014, 505, 412-416. [CrossRef] [PubMed]

58. Evans, C.M.; Raclawska, D.S.; Ttofali, F.; Liptzin, D.R.; Fletcher, A.A.; Harper, D.N.; McGing, M.A.; McElwee, M.M.; Williams, O.W.; Sanchez, E.; et al. The polymeric mucin Muc5ac is required for allergic airway hyperreactivity. Nat. Commun. 2015, 6, 6281. [CrossRef] [PubMed]

59. Lachowicz-Scroggins, M.E.; Yuan, S.; Kerr, S.C.; Dunican, E.M.; Yu, M.; Carrington, S.D.; Fahy, J.V. Abnormalities in MUC5AC and MUC5B Protein in Airway Mucus in Asthma. Am. J. Respir. Crit. Care Med. 2016, 194, 1296-1299. [CrossRef] [PubMed]

60. Bonser, L.R.; Zlock, L.; Finkbeiner, W.; Erle, D.J. Epithelial tethering of MUC5AC-rich mucus impairs mucociliary transport in asthma. J. Clin. Investig. 2016, 126, 2367-2371. [CrossRef] [PubMed]

61. Erle, D.J.; Sheppard, D. The cell biology of asthma. J. Cell Biol. 2014, 205, 621-631. [CrossRef] [PubMed]

62. Woodruff, P.G.; Modrek, B.; Choy, D.F.; Jia, G.; Abbas, A.R.; Ellwanger, A.; Koth, L.L.; Arron, J.R.; Fahy, J.V. T-helper type 2-driven inflammation defines major subphenotypes of asthma. Am. J. Respir. Crit. Care Med. 2009, 180, 388-395. [CrossRef] [PubMed]

63. Sigurdsson, H.H.; Kirch, J.; Lehr, C.M. Mucus as a barrier to lipophilic drugs. Int. J. Pharm. 2013, 453, 56-64. [CrossRef] [PubMed]

64. Wegmann, M.; Fehrenbach, H.; Fehrenbach, A.; Held, T.; Schramm, C.; Garn, H.; Renz, H. Involvement of distal airways in a chronic model of experimental asthma. Clin. Exp. Allergy 2005, 35, 1263-1271. [CrossRef] [PubMed]

65. Baker, G.L.; Shultz, M.A.; Fanucchi, M.V.; Morin, D.M.; Buckpitt, A.R.; Plopper, C.G. Assessing gene expression in lung subcompartments utilizing in situ RNA preservation. Toxicol. Sci. 2004, 77, 135-141. [CrossRef] [PubMed]

66. Mattfeldt, T.; Mall, G.; Gharehbaghi, H.; Moller, P. Estimation of surface area and length with the orientator. J. Microsc. 1990, 159, 301-317. [CrossRef] [PubMed]

67. Weibel, E.R.; Hsia, C.C.W.; Ochs, M. How much is there really? Why stereology is essential in lung morphometry. J. Appl. Physiol. 2007, 102, 459-467. [CrossRef] [PubMed]

68. Crouzier, T.; Beckwitt, C.H.; Ribbeck, K. Mucin Multilayers Assembled through Sugar-Lectin Interactions. Biomacromolecules 2012, 13, 3401-3408. [CrossRef] [PubMed]

69. Kawano, K.; Uehara, F.; Sameshima, M.; Ohba, N. Application of lectins for detection of goblet cell carbohydrates of the human conjunctiva. Exp. Eye Res. 1984, 38, 439-447. [CrossRef]

70. Chazotte, B. Labeling membrane glycoproteins or glycolipids with fluorescent wheat germ agglutinin. Cold Spring Harb. Protoc. 2011, 2011, pdb.prot5623. [CrossRef] [PubMed]

71. Graziadei, G.A.; Graziadei, P.P. Neurogenesis and neuron regeneration in the olfactory system of mammals. II. Degeneration and reconstitution of the olfactory sensory neurons after axotomy. J. Neurocytol. 1979, 8 , 197-213. [CrossRef] [PubMed]

(C) 2018 by the authors. Licensee MDPI, Basel, Switzerland. This article is an open access article distributed under the terms and conditions of the Creative Commons Attribution (CC BY) license (http:/ / creativecommons.org/licenses/by/4.0/). 